\title{
Kepemimpinan Kiai dalam Mengembangkan Kurikulum Pendidikan di Pondok Pesantren
}

\section{(Studi Kasus: Pondok Pesantren al-Rifaie 2 Gondanglegi, Pondok Pesantren Miftahul Ulum Putri Ganjaran, dan Pondok Pesantren Rakyat al- Amin Malang).}

\author{
Yazidul Busthomi \\ Institut Agama Islam Al-Qolam Gondanglegi Malang, Indonesia \\ yazidulbusthomi03@gmail.com \\ Syamsul A'dlom \\ Institut Agama Islam Al-Qolam Gondanglegi Malang, Indonesia
}

Abstract: The main capital that causes a Kiai to succeed in developing education in Islamic boarding schools is, in essence, extraordinary knowledge in his leadership in developing education in his Islamic boarding school. So that education in Islamic boarding schools that are developing at this time is solely dependent on the leadership of the Kiai in developing his education. Based on the description of the problem, the researcher raised the title "Kiai Leadership in developing educational curriculum in Islamic boarding schools (case study: Pondok Pesantren al-Rifaie 2 Gondanglegi, Islamic Boarding School Miftahul Ulum Putri Ganjaran, and Islamic Boarding Schools of the People of al-Amin Malang). background of the problem that has been explained above, then the problem formulation can be taken, namely: 1. How is the leadership of the Kiai in developing the education curriculum at Pondok Pesantren al-Rifaie 2 Gondanglegi Malang? 2. How is Kiai's leadership in developing the education curriculum at Miftahul Ulum Islamic Boarding School in Ganjaran Gondanglegi Malang? 3. How is Kiai's leadership in developing an educational curriculum at Pondok Pesantren Rakyat alAmin Malang? In order to obtain truly valid data in this study, the researcher needs to determine the appropriate data collection techniques. Therefore, researchers use the following techniques: 1. Interview techniques, 2. Observation techniques, 3. Documentation techniques. From the results of research conducted by researchers to describe the leadership of Kiai in developing an educational curriculum in Islamic boarding schools (case study: Pondok Pesantren 
al-Rifaie 2 Gondanglegi, Islamic Boarding School Miftahul Ulum Putri Ganjaran, and Islamic Boarding Schools of al-Amin Malang), it can be concluded the results of the data namely three Kiai in developing educational curricula in their respective Islamic boarding schools, by submitting to heads of fields or units in developing educational curricula, and using responsive leadership models.

Keywords: Leadership, Clerics, Education

\section{Pendahuluan}

Pada zaman sekarang, ketika kehidupan manusia semakin berkembang, maka keinginan untuk menghadirkan ajaran agama yang sesuai dengan kebutuhan masyarakat menjadi suatu kebutuhan yang sangat penting yang tidak bisa dihindari lagi. Karena sebagaimana dapat diketahui betapapun istimewanya ajaran Islam yang dijelasakan al-Qur'an, ajaran tersebut tidak akan mempunyai makna luas ketika tidak mampu dijabarkan menjadi panduan operasional-fungsional yang dapat dirasakan bagi kebutuhan umat Islam. Untuk itu dibutuhkan alat penyampaian ajaran Islam yang baik dan mengena pada umat Islam, alat tersebut adalah berupa dakwah Islam dengan berbagai komponennya.

Mengingat aktivitas santri tidak terlepas dari masyarakat, maka perkembangannya seharusnya juga mengimbangi atau berbanding lurus dengan perkembangan masyarakat, artinya aktivitas santri hendaknya dapat mengikuti perkembangan dan perubahan masyarakat, sehingga aktivitas santri tidak hanya menjadi pelengkap hidup semata akan tetapi, lebih dari itu yaitu sebagai roda dalam mengiringi perkembangan masyarakat moderen sekarang.

Santri pada era kontemporer ini dihadapkan pada berbagai tantangan dan problematika yang semakin kompleks. Hal tersebut tidak 
terlepas dari adanya perubahan dan perkembangan dinamika masyarakat yang semakin maju dan moderen. Perkembangan era teknologi dan transportasi yang begitu canggih secara tidak sadar telah menggiring umat manusia pada pilihan. Satu sisi, pilihan tersebut membawa hikmah dan manfaat bagi kehidupan manusia, akan tetapi disisi lain perkembangan tersebut juga membawa dampak yang kurang baik. Mengingat aktivitas santri tidak terlepas dari masyarakat, maka perkembangan pendidikannya seharusnya juga mengimbangi atau berbanding lurus dengan perkembangan masyarakat, artinya aktivitas santri hendaknya dapat mengikuti perkembangan dan perubahan masyarakat, sehingga aktivitas santri tidak hanya menjadi pelengkap hidup semata, akan tetapi lebih dari itu yaitu sebagai roda dalam mengiringi perkembangan masyarakat moderen sekarang.

Berdasarkan penjelasan di atas, maka kiai di Pondok pesantren harus mampu mengembangkan pendidikan di pondok pesantrennya, agar semua santrinya memiliki pendidikan yang unggul, baik dalam pendidikan agama Islam maupun pendidikan pada teknologi kemajauan zaman, dan dapat diandalkan dalam berdakwah. Modal utama yang menyebabkan seorang Kiai berhasil dalam mengembangkan pendidikan di pondok pesantren pada pokoknya adalah pengetahuan yang luar biasa dalam kepemimpinannya mengembangkan pendidikan di pondok pesantrennya. Sehingga pendidikan di pondok pesantren yang berkembang saat ini adalah semata-semata tergantung pada kepemimpinan Kiai dalam mengembangkan pendidikannya. Berdasarkan uraian masalah tersebut, maka peneliti mengangkat sebuah judul "Kepemimpinan Kiai dalam mengembangkan kurikulum pendidikan di pondok pesantren (studi kasus: Pondok Pesantren al- 
Yazidul Busthomi / Syamsul A'dlom

Rifaie 2 Gondanglegi, Pondok Pesantren Miftahul Ulum Putri Ganjaran, dan Pondok Pesantren Rakyat al-Amin Malang).

\section{Landasan Teori}

\section{Sejarah Pesantren}

Pesantren di Indonesia baru diketahui keberadaan dan perkembangannya setelah abad ke 16. Pesantren-pesantren besar yang mengajarkan berbagai kitab Islam klasik dalam bidang fikih, teologi dan tasawuf. Pesantren ini kemudian menjadi pusat-pusat penyiaran Islam. Dalam catatan sejarah, Pondok pesantren dikenal di Indonesia sejak zaman Walisongo. Ketika itu Sunan Ampel mendirikan sebuah padepokan di Ampel Surabaya dan menjadikannya pusat pendidikan di Jawa. Para santri yang berasal dari pulau Jawa datang untuk menuntut ilmu agama. Bahkan di antara para santri ada yang berasal dari Gowa dan Talo, Sulawesi. Pesantren Ampel merupakan cikal bakal berdirinya pesantren-pesantren di Tanah Air. Sebab para santri setelah menyelesaikan studinya merasa berkewajiban mengamalkan ilmunya di daerahnya masing-masing. Pesantren sebagai komunitas dan sebagai lembaga pendidikan yang besar jumlahnya dan luas penyebarannya diberbagai pelosok tanah air telah banyak memberikan saham dalam pembentukan manusia Indonesia yang relegiyus (Ahmad Tafsir, 2014, p.191).

Kesederhanaan pesantren dahulu sangat terlihat, baik segi fisik bangunan, metode, bahan kajian dan perangkat belajar lainnya. Hal itu dilatarbelakangi kondisi masyarakat dan ekonomi yang ada pada waktu itu. Yang menjadi ciri khas dari lembaga ini adalah rasa keikhlasan yang dimiliki para santri dan sang Kiai. Hubungan mereka tidak hanya 
sekedar sebagai murid dan guru, tapi lebih seperti anak dan orang tua. Tidak heran bila santri merasa kerasan tinggal di pesantren walau dengan segala kesederhanaannya. Bentuk keikhlasan itu terlihat dengan tidak dipungutnya sejumlah bayaran tertentu dari para santri, mereka bersama-sama bertani atau berdagang dan hasilnya dipergunakan untuk kebutuhan hidup mereka dan pembiayaan fisik lembaga, seperti lampu, bangku belajar, tinta, tikar dan lain sebagainya. Keunggulan utama pada pendidikan pesantren adalah penanaman keimanan (Ahmad Tafsir, 2014, p.203).

Pesantren adalah lembaga pendidikan Islam yang tertua di Indoesia, setelah rumah tangga. Bila orang menulis tentang pesantren maka topik-topik yang harus ditulis sekurang-kurangnya adalah:

1. Kiai pesantren, mungkin mencakup ideal Kiai untuk zaman kini dan nanti,

2. Pondok, akan mencakup syarat-yarat fisik dan nonfisik, pembiayaan, tempat, penjagaan dan lain-lain,

3. Masjid, cakupannya akan sama dengan pondok,

4. Santri, melingkupi masalah syarat, sifat dan tugas santri,

5. Kitab kuning, bila diluaskan akan mencakup kurikulum pesantren dalam arti yang luas (Ahmad Tafsir, 2014, p.191).

Tujuan pendidikan pesantren, antara lain sebagai berikut yaitu:

1. Memiliki kebijaksanaan menurut ajaran Islam. Anak didik dibantu agar mampu memahami makna hidup, keberadaan, peranan, serta tanggung jawabnya dalam kehidupan di masyarakat.

2. Memiliki kebebasan yang terpimpin. Setiap manusia memiliki kebebasan, tetapi kebebasan itu harus dibatasi karena kebebasan memiliki potensi anarkisme. 
3. Berkemampuan mengatur diri sendiri. Di pesantren, santri mengatur sendiri kehidupannya menuruti batasan yang diajarkan agama.

4. Memiliki rasa kebersamaan yang tinggi. Dalam pesantren berlaku prinsip: dalam hal kewajiban, individu harus menunaikan kewajiban lebih dahulu, sedangkan dalam hal hak, individu harus mendahulukan kepentingan orang lain sebelum kepentingan diri sendiri.

5. Menghormati orang tua dan guru. Ini memang ajaran agama. Tujuan ini tercapai antara lain melalui penegakan berbagai pranata di pesantren seperti mencium tangan guru, tidak membantah guru.

6. Cinta kepada ilmu. Menurut al-Qur'an ilmu datang dari Allah. Banyak hadits yang mengajarkan pentingnya menuntut ilmu dan menjaganya. Karena itu orang-orang pesantren cenderung memandang ilmu sebagai sesuatu yang suci dan tinggi.

7. Mandiri. Jika mengatur diri sendiri kita sebut otonomi, maka mandiri yang dimaksud adalah berdiri atas kekuatan sendiri. Sejak awal santri telah dilatih untuk mandiri.

8. Kesederhanaan. Dilihat secara lahiriah sederhana memang mirip dengan miskin. Padahal yang dimaksud sedehana yang di pesantren adalah sikap hidup, yaitu memandang sesuatu, terutama materi, secara wajar, proporsional, dan fungsional. Sebenarnya banyak santri yang berlatar belakang orang kaya, tetapi mereka dilatih hidup sederhana (Ahmad Tafsir, 2014, p.202).

Setiap lembaga pendidikan, termasuk pesantren dituntun untuk memberikan pelayanan sebaik mungkin kepada pelanggannya. Agar 
dapat melakukan hal tersebut dengan baik, pesantren perlu dukungan sistem manajemen yang baik. Beberapa ciri sistem manajemen yang baik adalah pola pikir yang teratur, pelaksanaan kegiatan yang teratur, dan penyikapan terhadap tugas-tugas kegiatan secara baik (M. Sulthon Masyhud dan Moh. Khusnurdilo, 2003, p.23).

Dalam rangka mencapai visi dan misi pondok pesantren yang agung yaitu mengembangkan pendidikan, maka sebaiknya Kiai sebagai pemimpin pondok pesantren mempertimbangkan saran-saran sebagai berikut:

1. Mengadaptasikan kurikulum

2. Mendayagunakan otoritas pesantren yang besar

3. Menempatkan guru dan staf dalam team work yang solid

4. Melakukan pengembangan mutu guru berdasarkan rencana yang jelas

5. Melaksanakan pengembangan program bagi guru

6. Mengembangkan kualitas guru melalui kerjasama dengan instansi terkait seperti Depag dan Depdiknas

7. Memberi penghargaan yang istimiwa bagi guru dengan prestasi dan kinerja yang baik (M. Sulthon Masyhud dan Moh. Khusnurdilo, 2003, p.41).

Kepemimpinan responsif merupakan bagian dari kepemimpinan transpormatif yang tanggap terhadap kebutuhan santri, komunitas pesantren dan masyarakat luas. Jenis kepemimpinan ini penting, mengingat lembaga pondok pesantren di samping berdiri atas inisiatif Kiai sebagai pengasuh, namun perkembagannya tetap melibatkan dukungan masyarakat. Oleh karena itu, menjadi hal yang wajar bahwa Kiai sebagai pengasuh pondok pesantren menyampaikan informasi- 
informasi penting tentang kepercayaan yang diberikan kepada pemimpin pondok pesantren. Dapat diidealisasikan sosok pemimpin pondok pesantren responsif sebagai berikut:

1. Pemimpin pondok pesantren yang responsif akan selalu berpegang kepada prinsip bahwa pondok pesantren merupakan lembaga untuk memberikan pelayaan kepada komunitas pesantren (santri, wali santri dan ustadz) dan masyarakat luas.

2. Pemimpin pondok pesantren yang responsif akan senantiasa terbuka dan ikhlas untuk menampung aspirasi dan harapan masyarakat untuk kemajuan lembaganya.

3. Pemimpin pondok pesantren yang responsif mampu bekerjasama dengan pihak lain dalam rangka memelihara dan mengayomi budaya pesantren yang berbasis pada nilai-nilai moral, etik dan spiritual yang Islami (M. Sulthon Masyhud dan Moh. Khusnurdilo, 2003, p.44).

Pengembangan kurikulum pendidikan di pondok pesantren merupakan proses pengembangan kurikulum atau perbaikan dari kurikulum yang sudah ada. Berikut ini adalah beberapa karakteristik dalam pegembangan kurikulum:

1. Rencana kurikulum harus dikembangkan dengan tujuan yang jelas.

2. Suatu program yang dilaksanakan merupakan bagian dari kurikulum yang dirancang selaras dengan prosedur pengembanagan kurikulum.

3. Rencana kurikulum harus mengenalkan dan mendorong diversitas di antara para pelajar. 
4. Rencana kurikulum harus menyiapkan semua aspek situasi belajar mengajar, seperti tujuan, penjadwalan, dan fasilitas yang menunjang.

5. Rencana kurikulum harus dikembangkan sesuai dengan karakteristik siswa/santri.

6. Pendekatan kurikulum yang banyak digunakan.

7. Rencana kurikulum sebaiknya merefleksikan keseimbangan antara kognitif, afektif, dan psikomotorik (Oemar Hamalik, 2011, p.185).

Dalam garis besarnya kurikulum pendidikan di pondok pesantren dapat dikembangkan melalui tahap-tahap sebagai berikut yaitu:

1. Melakukan kajian kebutuhan untuk memperoleh faktor-faktor penentu kurikulum serta latar belakangnya.

2. Menentukan bahan ajar yang akan diajarkan.

3. Merumuskan tujuan pembelajaran.

4. Menentukan hasil belajar yang diharapkan dari siswa/santri dalam tiap mata pelajaran.

5. Menentukan topik-topik tiap-tiap mata pelajaran.

6. Menentukan syarat-syarat yang dituntut dari siswa/santri.

7. Menentukan bahan yang harus dibaca siswa/santri.

8. Menentukan alat evaluasi hasil belajar siswa/santri serta skala penilaiannya (M. Sulthon Masyhud dan Moh. Khusnurdilo, 2003, p.81). 


\section{Metode Penelitian}

\section{Jenis Penelitian}

Penelitian merupakan penelitian kualitatif dengan menggunakan rancangan studi multisitus, karena memang melibatkan tiga lokasi (situs) yang berbeda. Tiga situs tersebut adalah Pondok Pesantren alRifaie 2 Gondanglegi, Pondok Pesantren Miftahul Ulum Putri Ganjaran, dan Pondok Pesantren Rakyat al-Amin Malang. Pelibatan banyak kasus dalam penelitian ini dilatarbelakangi oleh titik tolak penelitian ini sendiri yang sejak awal memang, seperti dianjurkan oleh Robert Bogdan dan Sari K. Biklen, diorientasikan untuk mengembangkan teori tertentu (Robert Bogdan dan Sari K. Biklen, 1998, P.63). "Dalam penelitian kualitatif, seorang peneliti tidak diharapkan dan tidak dianjurkan memelihara asumsi dan keyakinan bahwa dirinya sangat tahu tentang fenomena yang berhak dikaji” (Burhan Bungin, 2013, p.48).

\section{Analisis Data}

Sebagai sebuah penelitian multikasus, penelitian ini menggunakan dua tahap teknik analisis seperti yang diarahkan oleh Josée Audet dan Gérald d'Amboise, yaitu (1) analisis data situs tunggal dan (2) analisis data lintas situs. Pada tahap pertama, data yang digali dari masing-masing situs, yakni ketiga pesantren yang menjadi lokasi penelitian ini, dianalisis secara induktif sesuai dengan pokok-pokok pemikiran yang penting terkait dengan kepemimpinan Kiai dalam mengembangkan kurikulum pendidikan di pondok pesantren. Pendekatan yang digunakan adalah pendekatan sosiologi integratif seperti yang ditawarkan oleh Ritzer. Langkah-langkah proseduralnya 
mengikuti model analisis interaktif yang ditawarkan oleh M.B. Miles dan A.M. Huberman (1994), yaitu pergerakan simultan dan berulangulang antara proses (1) pengumpulan data, (2) penyederhanaan data, (3) pemaparan data, dan (4) penarikan kesimpulan (M.B. Miles dan A.M. Huberman, 1994, p.12).

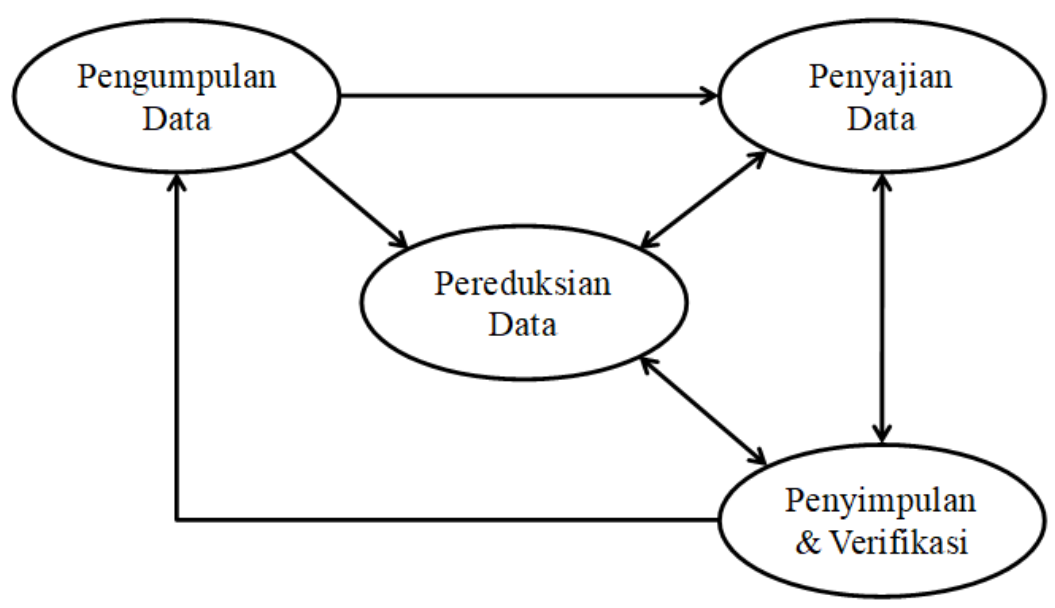

Analisis Data Interaktif pada Tahap Analisis Situs Tunggal

\section{Audit Hasil Penelitian}

Audit hasil penelitian dapat diartikan sebagai proses pemeriksaan terhadap alur analisis data untuk mengetahui proses munculnya kesimpulan penelitian. Auditor adalah seseorang yang ditunjuk melakukan audit terhadap suatu analisis data. Dalam mengaudit hasil analisis data penelitian kualitatif peneliti melakukan langkah-langkah sebagai berikut yaitu:

(1) Menentukan orang yang diminta kesediaanya menjadi auditor, yaitu Hasanuddin, S.H. adalah orang yang sangat mengetahui 
tentang penelitian yang diadakan oleh peneliti, misalnya tentang: rumusan masalah dan metodologi penelitian.

(2) Menyiapkan semua berkas yang akan diperlukan dalam mengaudit hasil analisis data.

(3) Menghubungi orang yang diminta kesediaannya menjadi auditor, yaitu Hasanuddin, S.H.

(4) Auditor yaitu Hasanuddin, S.H. mulai melakukan audit terhadap hasil analisis data.

\section{Hasil Penelitian}

Untuk memperoleh hasil yang lebih obyektif dalam penelitian ini, maka peneliti melakukan interviu langsung dengan Kiai atau informan yang bersangkutan, dan observasi di pondok pesantren agar hasil penelitian ini nantinya bisa dipertanggungjawabkan kebenarannya tanpa adanya manipulasi data yang akan dipaparkan. Hasil interviu, observasi dan dokumen, akan dijelaskan hasil datanya sebagai berikut:

Kepemimpinan Kiai dalam Mengembangkan Kurikulum Pendidikan di Pondok Pesantren al-Rifaie 2 Gondanglegi

Kepemimpinan Kiai dalam mengembangkan kurikulum pendidikan di Pondok Pesantren al-Rifaie 2 Gondanglegi yaitu dengan cara Dr. KH. Achmad Muflih Zamachsyari, SE., MM. menyerahkan ke bidang masing-masing dalam mengembangkan kurikulum pendidikan, misalnya bidang pendidikan diserahkan kepada Ustad H. Mahmud, M.Pd.I, Ustad H. Mahmud, M.Pd.I merancang lalu menyampaikan kepada Dr. KH. Achmad Muflih Zamachsyari, SE., MM., Dr. KH. Achmad Muflih Zamachsyari, SE., MM. setuju maka Ustad H. Mahmud, M.Pd.I melaksanakannya. Hal ini dapat diketahui dari hasil 
wawancara kepada derektor pendidikan Pondok Pesantren al-Rifaie 2 yaitu Ustad H. Mahmud, M.Pd.I, beliau mengatakan:

Di Pondok Rifaie sendiri ini, beda dengan pondok-pondok yang lain, kalau di pondok lain itu kan semuanya kan harus ikut dauh apa katanya Kiai, sedangkan di pondok kita ini Kiai menyerahkan ke bidang masing-masing, misalnya bidang pendidikan diserahkan kepada kami, bagaimana model dan lain-lainnya, kami merancang lalu kami aturkan kepada Kiai, Kiai setuju maka kita laksanakan itu model kita, jadi ini pendidikan ayok kita masukan bersama, kurikulum kita kembangkan bersama-sama bagaimana yang terbaik, itu Kiai.

Kepemimpinan Dr. KH. Achmad Muflih Zamachsyari, SE., MM. dalam megembangkan kurikulum pendidikan di Pondok Pesantren al-Rifaie 2 menggunkan model kepemimpinan responsif yaitu tanggap terhadap kebutuhan santri, komunitas pesantren dan masyarakat luas. Hal ini dapat diketahui dari hasil wawancara kepada derektor pendidikan Pondok Pesantren al-Rifaie 2 yaitu Ustad $\mathrm{H}$. Mahmud, M.Pd.I, beliau mengatakan:

Pondok kita ini memang sengaja untuk melayani masyarakat, makanya sekarang zaman seperti ini, ya kita sesuaikan dengan kebutuhan, pendidikan sekarang kita untuk masa depan, pendidikan saat ini tapi yang kita harapkan masa depan tidak ketinggalan, sehingga apapun disesuaikan dengan kondisi dan harapan masa depan, kalau kita lihat kurikulumnya sudah seperti itu, tidak menggunakan salaf murni, tapi kalaborasi antara kurikulum nasional dan pesantren. Jadi kalau masalah sarana dan prasarana memang kita upayakan terpenuhi apa yang dibutuhkan oleh zaman terkinian, tuntutan masyarakat, kurikulum, pemerintah, insyaAllah kita upayakan selalu terpenuhi. 
Selanjutnya peneliti melakukan observasi untuk menguatkan hasil temuan penelitian, diketahui oleh peneliti bahwa Kiai Abdullah memenuhi sarana dan prasarana yang dibutuhkan oleh santri dalam megembangkan kurikulum pendidikan di Pondok Pesantrennya dan juga menyediakan kantor khusus bagi derektor pendidikan. Dan kemudian peneliti meletakan foto tentang kantor khusus bagi derektor pendidikan, di lampiran-lampiran dalam laporan ini sebagai bukti dokumen.

\section{Kepemimpinan Kiai dalam Mengembangkan Kurikulum}

\section{Pendidikan di Pondok Pesantren Miftahul Ulum Putri Ganjaran}

Kepemimpinan Kiai dalam mengembangkan kurikulum pendidikan di Pondok Pesantren Miftahul Ulum Putri Ganjaran yaitu dengan cara KH. Muhammad menyerahkan ke bidang masing-masing dalam mengembangkan kurikulum pendidikan, dan menggunkan model kepemimpinan responsif. Hal ini dapat diketahui dari hasil wawancara kepada putra dari Kiai Pondok Pesantren Miftahul Ulum Putri yaitu Gus Mas'ud, beliau mengatakan:

Di pondok nika gih, contoh kepemimpina itu, mungkin lebih kepada uswah atau contoh. O gih (pengembangan kurikulum) sudah diserahkan kepada kepala unit, kalau beliau (Kiai Pondok Pesantren Miftahul Ulum Putri) sudah sifatnya hanya pengayom, dan ya pengambilan keputusan nanti berdasarkan masukan-masukan dari bawah untuk hal-hal yang sifatnya vital, kalau pengembangannya percaya kepada putra-putra kepada kepala bidang-bidang, (dalam merespon kebutuhan santri) ya memperhatikan, kalau itu sudah di bawah naungan bidangnya masing-masing. 
Kepemimpinan Kiai dalam Mengembangkan Kurikulum Pendidikan di Pondok Pesantren Rakyat al-Amin Malang

Kepemimpinan Kiai dalam mengembangkan kurikulum pendidikan di Pondok Pesantren Rakyat al-Amin Malang yaitu dengan cara Kiai Abdullah Sam memberi kekuasaan seluas-luasnya untuk mengembangkan kurikulum pendidikan di lembaganya kepada kepala unit atau guru-guru, sehingga mereka merasa memiliki terhadap Pesantren Rakyat al-Amin Malang dan menjadi pemimpin yang efektif dan efesien. Hal ini dapat diketahui dari hasil wawancara kepada Kiai Pondok Pesantren Rakyat al-Amin Malang yaitu Kiai Abdullah Sam, beliau mengatakan:

Jadi, kalau di Pesantren Rakyat ini cara saya menggerakan agar semua itu terlibat dalam mengembangkan kurikulum pendidikan pesantren maka kami memberi penghargaan kepada masing-masing kepala unit atau guru-guru dalam bentuk memberi kekuasaan seluasluasnya untuk mengembangkan unit-unit yang dia pegang, sehingga masing-masing guru atau kepala unit itu memiliki rasa memiliki terhadap Pesantren Rakyat, sehingga menjadi kepemimpinan yang efektif dan efesien tanpa banyak perintah, tanpa banyak komando karna masing-masing cukup tinggal melaporkan, mengkoordinasikan program-program yang dicanangkan oleh masing-masing unit, misalnya diniah ustad hasan punya program $\mathrm{ABCD}$ tinggal melaporkan ke derektor pendidikan.

Kepemimpinan Kiai Abdullah Sam, dalam megembangkan kurikulum pendidikan di Pondok Pesantren Rakyat al-Amin Malang menggunkan model kepemimpinan responsif yaitu Kiai Abdullah Sam, S.Psi dalam memimpin pendidikan di Pondok Pesantrennya selalu 
merespon terhadap kebutuhan sanrti-santrinya, dan terbuka untuk menerima gagasan/saran yang baik, dalam pengembangkan pendidikan di Pondok Pesantrennya. Hal ini dapat diketahui dari hasil wawancara kepada kepala diniah yaitu Ustad Hasanuddin, beliau mengatakan:

Kepemimpinan Kiai, dalam megembangkan kurikulum pendidikan di Pondok Pesantren ini menggunkan model kepemimpinan responsif yaitu Kiai Abdullah dalam memimpin pendidikan di Pondok Pesantrennya selalu merespon terhadap kebutuhan sanrti-santrinya terutama dalam hal pengembangan kurikulum pendidikan, sehingga masyarakat ikut mendukung dengan cara melibatkan diri sebagai tenaga mengajar di pondok pesantren ini, Kiai Abdullah berusaha keras untuk memenuhi sarana dan prasarana yang diperlukan dalam megembangkan kurikulum pendidikan di Pondok Pesantrennya. tidak hanya menyediakan pondok pesantren untuk memberikan pelayaan yang baik kepada semua santrinya, tetapi juga menyediakan rumah khusus bagi tenaga pengajar, agar proses megembangkan kurikulum pendidikan di pondok pesantrennya berjalan dengan lancar tanpa adanya hambatan. Kiai Abdullah sebagai pemimpin Pondok Pesantren ini terbuka untuk menerima gagasan/saran yang baik, dalam pengembangkan kurikulum pendidikan di Pondok Pesantrennya, terutama dari ustad yang mengajar di Pondok Pesantrennya.

Selanjutnya peneliti melakukan observasi untuk menguatkan hasil temuan penelitian, diketahui oleh peneliti bahwa Kiai Abdullah memenuhi sarana dan prasarana yang diperlukan dalam megembangkan kurikulum pendidikan di Pondok Pesantrennya dan juga menyediakan rumah khusus bagi tenaga pengajar. Dan kemudian peneliti meletakan 
foto tentang rumah khusus yang disedikan bagi tenaga pengajar, di lampiran-lampiran dalam laporan ini sebagai bukti dokumen.

\section{Kesimpulan}

Dari hasil penelitian yang peneliti lakukan untuk mendeskripsikan kepemimpinan Kiai dalam mengembangkan kurikulum pendidikan di pondok pesantren (studi kasus: Pondok Pesantren al-Rifaie 2 Gondanglegi, Pondok Pesantren Miftahul Ulum Putri Ganjaran, dan Pondok Pesantren Rakyat al-Amin Malang) maka dapat disimpulkan hasil datanya yaitu tiga Kiai dalam mengembangkan kurikulum pendidikan di pondok pesantrennya masing-masing, dengan cara menyerahkan kepada kepala bidang atau unit dalam mengembangkan kurikulum pendidikan, dan menggunkan model kepemimpinan responsif. 


\section{Daftar Rujukan}

Ahmad Tafsir, 2014. Ilmu Pendidikan dalam Perspektif Islam. Bandung: PT Remaja Rosdakarya.

Burhan Bungin. 2013. Analisis Data Penelitian Kualitatif. Jakarta: PT Raja Grafindo Persada.

M.B. Miles dan A.M. Huberman. 1994. Qualitative Data Analysis: an Expanded Sourcebook. California: Sage Publications Inc.

M. Sulthon Masyhud dan Moh. Khusnurdilo. 2013. Manajemen Pondok Pesantren. Jakarta: Diva Pustaka.

Masykuri Bakri. 2016. Metode Penelitian Kualitatif. Malang: Visipress Media.

Oemar Hamalik. 2016. Dasar Dasar Pengembangan Kurikulum. Bandung: PT Remaja rosdakarya.

Robert Bogdan dan Sari K. Biklen. 1998. Qualitative Research for Education: An Introduction to Theories and Methods. Boston: Allyn and Bacon Publisher.

Rulam Ahmadi. 2015. Memahami Metodologi Penelitian Kualitatif. Malang: Universitas Negeri Malang. 